\title{
SYNTHESIS OF BIMETALLIC CATALYSTS ON THE BASIS OF Y TYPE ZEOLITE
}

\author{
Kanaan R. Ahmed ${ }^{\mathrm{a}}$
}

${ }^{a}$ Dept. of Chemistry, Faculty of Science, University of Zakho, Kurdistan Region, Iraq- (kanaan.ahmed@uoz.edu.krd)

\begin{abstract}
:
In this work, it is shown that based onpowder zeolite type $\mathrm{Y}$, mono metallic and bimetalliccatalysts have been developed that are promising for petroleum chemistry processes. The method is based on the preparing hydrogen form of Y zeolite by ion exchange with a solution of ammonium nitrate at a starting concentration of $70 \mathrm{~g} \cdot \mathrm{l}^{-1}$ and nickel nitrate solution which provides Ni cations. Then after preparation of bimetallic catalysts by impregnating second metal by incipient wetness. All samples and catalysts were characterized using X-ray diffraction (XRD) analysis techniques, adsorption methods, and elemental analysis. The research results showed that in order to reach the degree of exchange of $\mathrm{Na}^{+}$for $\mathrm{H}^{+}$cations no less than 0.73 , it is necessary to carry ou $t$ four exchanges of $\mathrm{Na}^{+}$by $\mathrm{NH}_{4}^{+}$and three intermediate thermal treatments at $540^{\circ} \mathrm{C}$ for 3 to 4 hours in air atmosphere.
\end{abstract}

KEYWORDS: Bimetallic Catalysts, Zeolites, Petroleum Chemistry, Solid Acid Catalysts, Industrial Catalysts

\section{INTRODUCTION}

Zeolites as defined by Breck, D.W. (1974) are microporous materials with exceedingly limit pore distribution, and, therefore, they are described by volume filling of the intra crystal pore space in sorption of different molecules, with a substance being adsorbed present in this space in a nearly fluid space (Breck, D.W, 1974). Acid catalysts, especially zeolites and zeotypes, are utilized to an expansive degree in refining and petrochemical transfigurations (G. Ertl, et al., 2008), (H. van Bekkum, et al.), (G. Busca, 2007) and (C. Martinez, A. Corma, 2011).

Most of the works reported in the literature on zeolite catalysts studied the use of bifunctional catalysts, i.e., those with acid and metallic sites. Bifunctional zeolite catalysts, typically metal -charged acid zeolites, are used in many processes in the oil refining and petrochemical industries such as hydrocracking, reforming, dewaxing,

hydroisomerization of (C5

-C6) Paraffins,

hydroisomerization of $\mathrm{C} 5$ aromatic hydrocarbons and other processes (Bolton A.P., 1976) and (Minachev Kh.M. and Isakov Ya.I., 1976). In addition to a bifunctional catalyst with a single metal as a Lewis acid site, the use of bimetallic catalysts supported on Brønsted zeolites is also one of the most interesting topics as well as to improve the catalytic performance of thehydrodeoxygenation (HDO) reaction. For example, Wang et al. developed successfully the bimetallic $\mathrm{Ru}-\mathrm{M}-\mathrm{HY}(\mathrm{M}=\mathrm{Cu}, \mathrm{Ni}, \mathrm{Fe}, \mathrm{Zn})$ as catalysts for the HDO of compounds of the lignin type. They found that the eoharged $\mathrm{Ru}$ with transition metals exhibits the st rongest catalytic activity for paraffin synthesis (Liu, X.; et al., 2018), (Rensel, D. J.; et al., 2017), and (Resende, K. A.; et al., 2018).

As previous studies have stated (Jordão, M. H. and Cardoso, D., 2001), throughout the reduction process, metallic platinum formation is affected by the presence of nickel, it results in a decrease in the average particle size. Thus, bimetallic catalysts Pt-Ni-HUSY have particles smaller than monometallic Ni-HUSY and Pt-HUSY, and they have better dispersion for metallic function, which would explain they are significant growth activity for $\mathrm{n}$-C6 isomerization. Moreover, the results stated by (Jordão, M. H. and Cardoso, D., 2001) using various characterization methods indicate that an interaction between the $\mathrm{Pt}$ and $\mathrm{Ni}$ atoms in the metallic particles is created, leading to physical, chemical and catalytic changes.

As stated by (F. V. Barsi and D. Card oso, 2009), bifunctional monometallic $(\mathrm{Ni}$ or $\mathrm{Pt}$ ) and bimetallic catalysts (Pt and $\mathrm{Ni}$ ), using H-USY zeolite as the support, were prepared in order to confirm the role of the metal content and composition on the catalytic properties for $\mathrm{n}-\mathrm{C} 6$ isomerization. $\mathrm{T}$ he bimetallic catalysts demonstrated a higher activity in $n \quad$-hexane isomerization when compared to the monometallic ones.

By loading Ni and Co metal on $\mathrm{H}$-ZSM-5 zeolite, Vituruch Goodwin et al. (2017) prepared bimetallic catalysts to produce bimetallic zeol ite supported catalysts for catalytic pyrolysis reaction (for converting biomass to biofuel). $\mathrm{Ni}$ and Co metal were loaded on $\mathrm{H}$-ZSM-5 via wet impregnation method (Vituruch Goodwin et al., 2017). Gustavo Larsen., et al, (1994) showed that a series of PtNi-BEA-zeolite bimetallic catalysts ce impregnated for $n$-hexane aromatization were tested. Due to the importance of $\mathrm{Y}$ type zeolite in different cationdecatonated forms as catalysts used for petroleum chemistry processes to convert various forms of compounds, we aimed to develop bimetallic catalyst on the basis of this type of zeolite.

\section{EXPERIMENTAL}

\subsection{Starting Materials}

The starting material used to prepare all the zeolite samples and catalysts (Mono and Bimetallic) was $\mathrm{Na}-\mathrm{Y}$ zeolite, supplied by Nanjin XFNANO Materials Tech Co., Ltd. with the following characteristics as shown in table 1 . and figure 1 and 2

Table 1. Properties starting material NaY

\begin{tabular}{|c|c|}
\hline Appearance & White powder \\
\hline Particle size & $0.6-0.9 \mu \mathrm{m}$ \\
\hline $\mathrm{SiO}_{2} / \mathrm{Al}_{2} \mathrm{O}_{3}$ & $\geq 5.3$ \\
\hline Lattice constant & $2.45-2.48 \mathrm{~nm}$ \\
\hline Crystallinity & $\geq 88 \%$ \\
\hline LOI (Loss on ignition) & $\leq 15 \%$ \\
\hline Application fields & $\begin{array}{c}\text { Fluid catalytic cracking (FCC), } \\
\text { hydrocracking, isomerization } \\
\text { processes of oil refining. }\end{array}$ \\
\hline
\end{tabular}

* This is an open access under a CC BY -NC-SA 4.0 license (https://creativecommons.org/licenses/by -nc-sa/4.0/) 


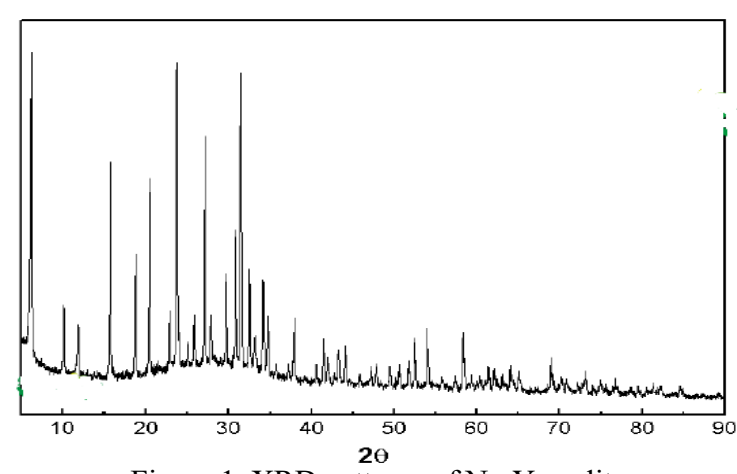

Figure 1. XRD patterns of $\mathrm{Na}-\mathrm{Y}$ zeolite

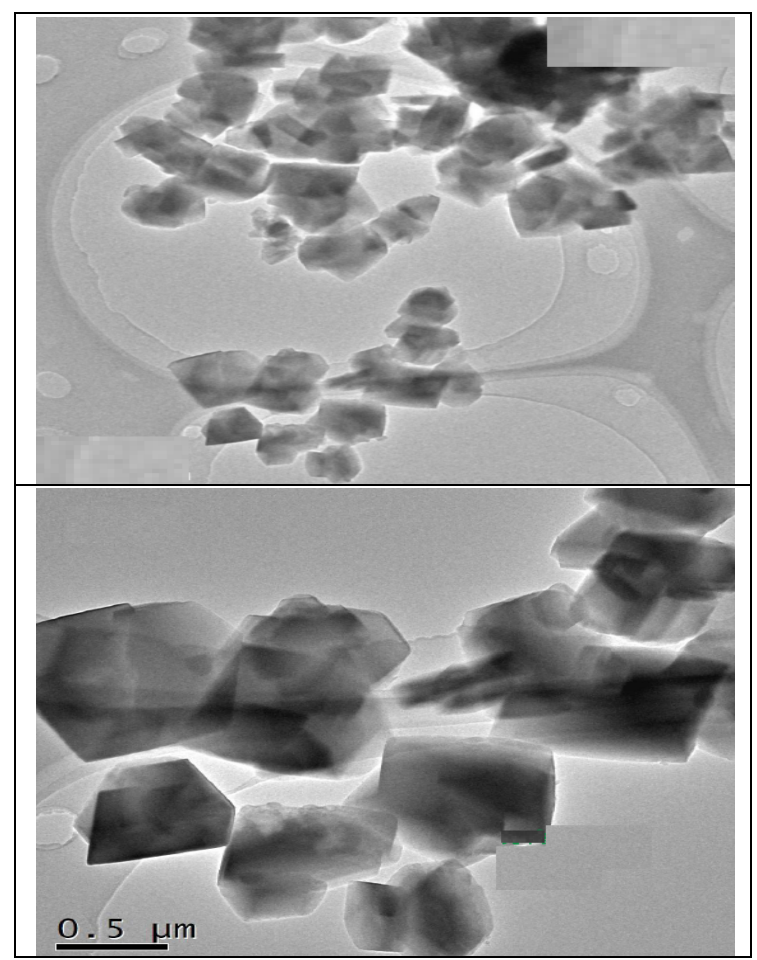

Figure 2. Transmission electron microscopy TEM graph of Na-Y zeolite

\subsection{Obtaining Hydrogen form Zeolite (Ion Exchange)}

The samples of $\mathrm{H}$-form (protonic form) $\mathrm{Y}$-zeolites were prepared by four ion exchanges of $\mathrm{Na}+$ cation to $\mathrm{NH} 4+$ cations (decationated) in an aqueous solution of ammonium nitrate at a starting concentration of $70{\mathrm{~g} . \mathrm{l}^{-1}}^{\text {(excess exchange }}$ ammonium cation with respect to sodium) under stirring in an isothermal batch reactor at $70-80{ }^{\circ} \mathrm{C}$ for 1 hour. All samples were then dried at $120-150{ }^{\circ} \mathrm{C}$ (ammonium form $\mathrm{NH}_{4} \mathrm{Y}$ ) and calcined at $540-550{ }^{\circ} \mathrm{C}$ for 4 hours $(\mathrm{H}-\mathrm{Y})$ in the atmosphere of air according to a procedure described in (KK Gorshunova, KRAhmed, OS Travkina, IN Pavlova, NG Grigor'eva, ML Pavlov, BI Kutepov, 2014).

\subsection{Monometallic Y type Zeolite Catalysts}

Precursors of Ni containing catalysts supported on NH4Y were obtained by competitive ion exchange involving metallic cations $\mathrm{Ni}\left(\mathrm{NO}_{3}\right)_{2}$ and $\mathrm{NH}_{4}^{+}$cations. After the exchange period of 1 hour under stirring, the solids were filtered, washed with distilled water, and dried at $150{ }^{\circ} \mathrm{C}$ for 2 hours. To determine the actual content of these metals in the solid, the filtrate obtained from each catalyst exchange was collected and then a metal analysis of these solutions were performed using atomic absorption spectrophotometry and flame photometry.

\subsection{Bimetallic Y type Zeolite Catalysts}

In this work, the catalysts were synthesized by impregnation the samples of $8 \mathrm{~g}$ of HNi-Y zeolites by $\left(1.14 \mathrm{~g} \mathrm{Cu}\left(\mathrm{NO}_{3}\right)_{2} .3 \mathrm{H}_{2} \mathrm{O}\right.$ and $1.32 \mathrm{~g} \mathrm{Fe}\left(\mathrm{NO}_{3}\right)_{3}$ in $\left.30 \mathrm{ml} \mathrm{H} \mathrm{H}_{2} \mathrm{O}\right)$ solution by incipient wetness, After stirring for 1 hour, samples were Soaked for 4 to 5 days at laboratory temperature until the solution has been dried. Followed by drying at $150{ }^{\circ} \mathrm{C}$ and calcining at $540{ }^{\circ} \mathrm{C}$ for 4 hours to ensure complete dehydration. The $\mathrm{Cu}$ and $\mathrm{Fe}$ content in both samples was the same and made $0.05 \%$ by weight.

\subsection{Catalyst characterization}

The zeolite samples and catalysts were characterized using X-ray diffraction (XRD) analysis techniques, adsorption methods, and elemental analysis. The phase composition of zeolite samples was determined by X-ray diffraction. X-ray powder diffraction patterns (XRD) of bimetallic supported zeolite catalysts were performed using PHILIPS-PW-1800 automated diffractometer. The chemical compositions of the liquid and solid phases were determined by flame photometry and atomic absorption spectrophotometry.

The adsorption properties of zeolites were characterized in terms of equilibrium adsorption capacity (mg.g-1) for water, benzene, and $n$-heptane vapors. The sorption capacities were measured using the desiccator technique (I. N. Pavlova1, O. S. Travkina1,*, B. I. Kutepov1, K. R. Ahmed2, A. F. Akhmetov, 2012) the desiccator technique based on the full saturation of the zeolite with adsorbate (water, benzene, and n-heptane) vapor under standard testing conditions $\left(\mathrm{T}=20-25^{\circ} \mathrm{C}, \mathrm{P} / \mathrm{Ps}=0.8\right)$ was used to determine their values. A test portion of a sample weighing $0.2-0.3 \mathrm{~g}$ was dehydrated in a muffle furnace at $400-450^{\circ} \mathrm{C}$ for $2-3 \mathrm{~h}$ and placed in a desiccator. The sample was weighed at fixed time intervals. The measurements stopped when a constant weight of the sample was achieved.

\section{RESULTS AND DISCUSSION}

The best ion exchange process is after removing all the water molecules from the zeolite. Also, when partial dehydration we get a less effective and less stable catalyst as well as a poor metal distribution on the catalyst surface and thus less surface area(Minachev Kh.M. \& Isakov Ya.I. (1976)). Therefor after their preparation, the zeolite samples were heated to ensure complete dehydration samples dried at $150 \pm 3{ }^{\circ} \mathrm{C}$ for 2 hours then calcined at $540{ }^{\circ} \mathrm{C}$ for 4 hours to decompose $\mathrm{NH}_{4}{ }^{+}$cations of the ammonium zeolite (NH4-USY), and also to achieve Brønsted (H-Y) acid sites. From table 2 and 3 show that in order to reach the degree of exchange of $\mathrm{Na}+$ for $\mathrm{H}^{+}$cations ( $\alpha$ $(\mathrm{Na} \rightarrow \mathrm{H})$ ) no less than 0.73 , it is necessary to carry out four exchanges of $\mathrm{Na}+$ for and three intermediate thermal treatments at $540{ }^{\circ} \mathrm{C}$ for 3 to 4 hours in air atmosphere. $[\alpha(\mathrm{Na} \rightarrow \mathrm{H})=0.73]$.

Table 2. Data of ion exchanges and the degree of exchange of $\mathrm{Na}^{+}$cations by $\mathrm{NH}_{4}{ }^{+}$cations in the powder $\mathrm{Y}$ zeolite

\begin{tabular}{|c|c|c|}
\hline Sample & $\% \mathrm{Na}_{2} \mathrm{O}$ & $\alpha \mathrm{Na} 2 \mathrm{O}$ \\
\hline Na-Y & 12.749 & \\
\hline $\begin{array}{c}\text { After Ion Exchange Na- } \\
\text { Y zeolite with NH4NO3 }\end{array}$ & 3.1 & 0.76 \\
\hline
\end{tabular}

Table 3. Data of ion exchanges and the degree of exchange of $\mathrm{Na}$ + cations by $\mathrm{Ni} 2+$ cations in the powder $\mathrm{Y}$ zeolite

\begin{tabular}{|l|l|l|}
\hline Sample & $\% \mathrm{Na}_{2} \mathrm{O}$ & $\alpha \mathrm{Na} 2 \mathrm{O}$ \\
\hline $\mathrm{NaHY}$ & 12.749 & - \\
\hline $\begin{array}{l}\text { After Ion Exchange NaHY } \\
\text { zeolite with Ni(NO3)2 }\end{array}$ & 3.4 & 0.73 \\
\hline
\end{tabular}


X-ray diffractograms of zeolite samples, mono and bimetallic supported zeolite catalysts are demonstrated in Fig. 3. The results of XRD showed that impregnation method has reduced the crystallinity of zeolite supported catalyst FeNi-Y type zeolite. FeNi Y type zeolite prepared with impregnation has very little defined peaks.

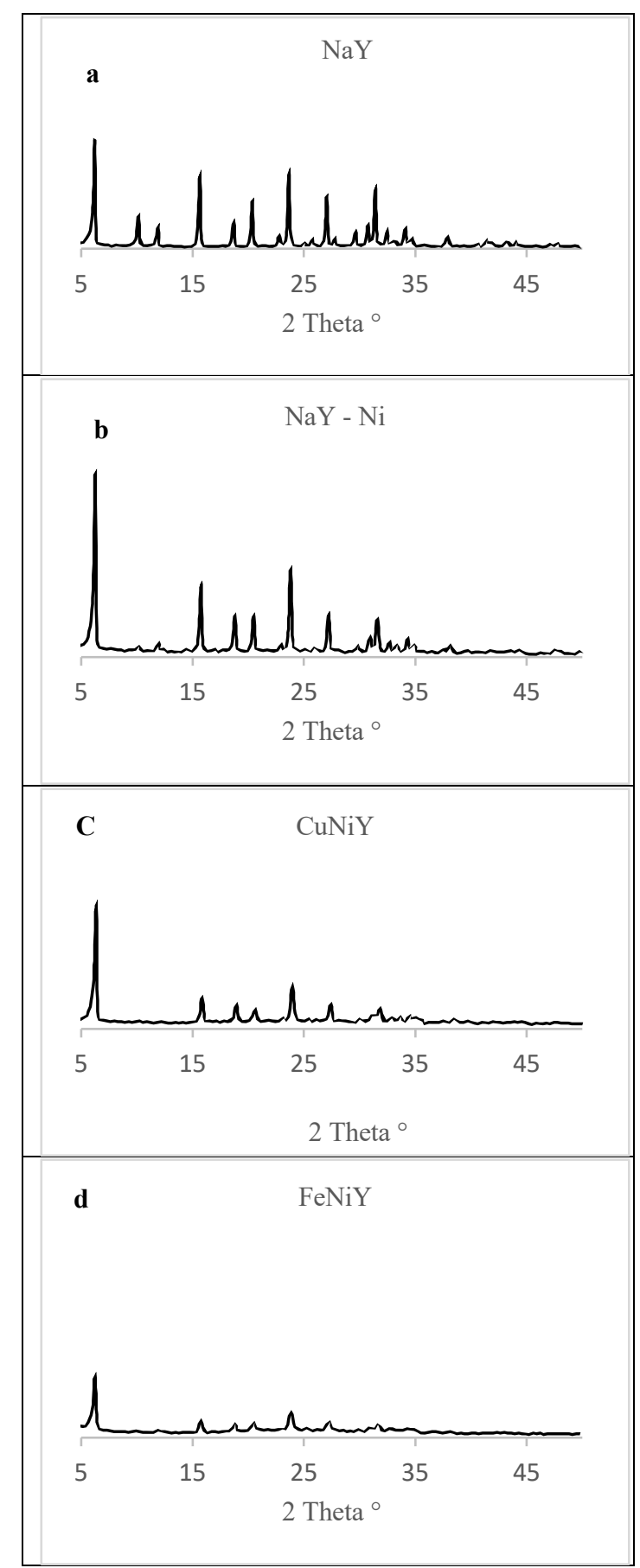

Figure 3. X-ray diffraction patterns of Zeolite sample and catalysts obtained by ion exchanges and impregnating of metals for: a) Y type zeolite b) Ni-Y zeolite c) CuNi-Y zeolite d) FeNizeolite

According to the XRD data and values of the adsorption characteristics of the zeolites, the degree of crystallinity is not changed sharply for all the samples of Y type zeolite and catalysts prepared except for the sample loaded with iron cation which show lower crystallinity degree than other samples which is associated with the type of salt used to complete impregnating of iron metals over zeolite sample (see Experimental part).

Table 4. Illustrates Equilibrium adsorption capacities $\left(\mathrm{cm}^{3} \cdot \mathrm{g}^{-1}\right)$ of Y-type zeolite and prepared catalysts. From the above results it is seen that on the Na-Y zeolite sample, the equilibrium adsorption capacity for water, benzene and $\mathrm{n}$-heptane vapors are $0.30,0.39$ and 0.35 respectively. Therefore, in the other samples, the adsorption rate is slightly lower. It is also characterized by a lower value of the equilibrium adsorption capacity for water, benzene, and $n$-heptane vapors since it has bigger sizes of crystal intergrowths.

Table 4. The values of equilibrium adsorption capacities $\left(\mathrm{cm}^{3} \cdot \mathrm{g}^{-}\right.$ $\left.{ }^{1}\right)$ for water vapor $\left(\mathrm{H}_{2} \mathrm{O}\right)$, benzene $\left(\mathrm{C}_{6} \mathrm{H}_{6}\right)$ and heptane $\left(\mathrm{n}-\mathrm{C}_{7} \mathrm{H}_{16}\right)$ of the resulting products.

\begin{tabular}{|c|c|c|c|}
\hline \multirow[t]{2}{*}{ Sample } & \multicolumn{3}{|c|}{$\begin{array}{c}\text { Equilibrium adsorption capacity }\left(20^{\circ} \mathrm{C} \text { and } \mathrm{P} / \mathrm{Ps}\right. \\
=0.8), \\
(\mathrm{cm} 3 / \mathrm{g}) \text { for vapor of: }\end{array}$} \\
\hline & $\mathrm{H}_{2} \mathrm{O}$ & $\mathrm{C}_{6} \mathrm{H}_{6}$ & $\mathrm{n}-\mathrm{C}_{7} \mathrm{H}_{16}$ \\
\hline $\mathrm{NaY}$ & 0.30 & 0.39 & 0.35 \\
\hline NH4Y & 0.25 & - & 0.27 \\
\hline $\mathrm{NiY}$ & 0.29 & 0.35 & 0.30 \\
\hline CuNiY & 0.26 & 0.34 & 0.30 \\
\hline FeNiY & 0.24 & 0.32 & 0.27 \\
\hline
\end{tabular}

\section{CONCLUSION}

In this paper, the method for the synthesis of bimetallic catalysts based on Y type zeolite structure of high crystallinity mordenite has been presented. Synthesis conditions of different cationateddecationated forms of Y type zeolite were determined, and their adsorption properties were also studied. Synthesis of high phase purity Y type zeolite (catalys) was developed, starting with Na$\mathrm{Y}$ zeolite having a molecular ratio of $\mathrm{SiO}_{2} / \mathrm{Al}_{2} \mathrm{O}_{3}=5.3$ and crystallinity degree more than $88 \%$.

\section{ACKNOWLEDGEMENT}

The analysis of the obtained compounds was performed at Institute of Petrochemistry and Catalysis of the Russian Academy of Sciences (Ufa).

\section{REFERENCES}

Barsi F. V. \& Cardoso D. (2009), Bimetallic Pt-Ni Catalysts Supported on USY Zeolite for n-C6 Isomerization, Brazilian Journal of Chemical Engineering, Vol. 26, No. 02, pp. 353 - 360.

Breck, D.W. (1974). Zeolite Molecular Sieves: Structure, Chemistry and Use, John Wiley \& Sons Inc., New York.

Bolton A.P. (1976), Zeolite Chemistry and Catalysis, ACS Monograph 171 (American Chemical Society, Washington, p.C.,) 714779 .

Busca G. (2007). Acid catalysts in industrial hydrocarbon chemistry, Chemical Reviews Vol. 107 p5366.

Ertl G., Knözinger H., Schüth F. \& Weitkamp J. (2008). Handbook of Heterogeneous Catalysis, Wiley-VCH Verlag GmbH \& Co. $\mathrm{KGaA}$, Weinheim, Chapt. 13 and14.

Gorshunova KK, Ahmed KR, Travkina OS, Pavlova IN, Grigor'eva NG, Pavlov ML, \& Kutepov BI. (2014), Influence of synthesis conditions on the adsorption and catalytic properties of mordenite zeolite, Petroleum Chemistry, Vol. 54, No. 2, pp. $132-136$.

Jordão, M. H. \& Cardoso, D. (2001), Characterization of Ni, Pt Zeolite Catalysts by TEM and EDX. Studies in Surface Science and Catalysis, 135, 357.

Martinez C. \& Corma A. (2011), Coordination Chemistry Reviews, Volume 255, Issues 13-14, 1558-1580.

Minachev Kh.M. \& Isakov Ya.I. (1976), Metal-containing Zeolites in Catalysis, Science Publishing, Moscow, 11-611. 
Liu, X.; An, W.; Wang, Y.; Turner, C. H.; \& Resasco, D. E. (2018), Hydrodeoxygenation of Guaiacol over Bimetallic FeAlloyed (Ni, Pt) Surfaces: Reaction Mechanism, Transition-State Scaling Relations and Descriptor for Predicting $\mathrm{C}-\mathrm{O}$ bond Scission Reactivity. Catal. Sci. Technol. 8, 2146-2158.

Pavlova1 I. N., Travkina1O. S., Kutepov B. I., Ahmed K. R., \& Akhmetov A. F. (2012), Synthesis and Properties Exchange Forms of Granulated Binder-free Zeolite X, International Journal of Materials Engineering, 2(6): 8083.

Rensel, D. J.; Kim, J.; Jain, V.; Bonita, Y.; Rai, N. \&Hicks, J. C. (2017), Composition-Directed Fe X Mo 2- XP Bimetallic Catalysts for Hydrodeoxygenation Reactions. Catal. Sci. Technol., 7, 1857-1867.
Resende, K. A.; Teles, C. A.; Jacobs, G.; Davis, B. H.; Cronauer, D. C.; Kropf, A. J.; Marshall, C. L.; Hori, C. E. \& Noronha, F. B. (2018), Hydrodeoxygenation of Phenol over Zirconia Supported Pd Bimetallic Catalysts: The Effect of Second Metal on Catalyst Performance. Appl. Catal., B, 232, 213-231.Van Bekkum H., Flanigen E.M., Jacobs P.A. \& Jansen J.C (2001) Introduction to Zeolite Science and Practice, vol. 137, Stud. Surf. Sci. Catal., 747-955.

Vituruch G. et al. (2017), Zeolite Supported Bimetallic Catalyst System: The Effect of Metal Loading for Catalytic Pyrolysis of Jatropha Residue, Key Engineering Materials Journal, 2017, Vol. 751, 494-499. 